\title{
Pengaruh Model Pembelajaran ABC Games Terhadap Keterampilan Berpikir Kritis Siswa Kelas IV SDN Biro Palu
}

\author{
Azizah $^{1}$, Shalehuddin ${ }^{2}$, Yun Ratna Lagandesa ${ }^{3}$ \\ 1,2 Progras Studi PGSD FKIP Universitas Tadulako \\ ${ }^{3}$ Program Studi Pendidikan Bahasa Inggris FKIP Universitas Tadulako \\ 1azizah.pgsd@untad.co.id \\ ${ }^{2}$ shalehuddinpettalolo1979@gmail.com
}

\begin{abstract}
ABSTRAK
Penelitian ini bertujuan untuk mengetahui pengaruh model pembelajaran ABC Games terhadap Keterampilan Berpikir Kritis Siswa Kelas IV SDN Biro Palu. Penelitian ini menggunakan jenis penelitian kuantitatif dengan menggunakan metode eksperimen. Desain eksperimen yang digunakan dalam penelitian ini yaitu quasi eksperimental design (eksperimen semu) bentuk nonequivalent control group design. Subjek dalam penelitian ini adalah seluruh siswa kelas IV SDN Biro Palu. Sampel ini diklasifikasi ke dalam 2 kelompok yaitu kelompok kelas eksperimen dan kelompok kelas kontrol. Teknik analisis data untuk menjawab hipotesis dalam penelitian ini adalah menggunakan Uji-t. Hasil analisis uji-t menunjukan bahwa nilai sign. (2-tailed) sebesar $0,001<0,05$. Hal ini berarti bahwa $\mathrm{H}_{\mathrm{o}}$ yang berbunyi Model pembelajaran ABC Games berpengaruh positif terhadap nilai keterampilan berpikir kritis siswa Kelas IV SDN Biro Palu dapat diterima. Sehingga dapat disimpulkan bahwa Model pembelajaran $A B C$ Games berpengaruh positif terhadap nilai keterampilan berpikir kritis siswa. Artinya penggunakan model pembelajaran ABC dapat meningkatkan keterampilan berpikir kritis siswa.
\end{abstract}

Kata kunci: Model Pembelajaran ABC Games, Keterampilan Berpikir Kritis, Siswa SD

\begin{abstract}
This study aims to determine the effect of the ABC Games learning model on the Critical Thinking Skills of Class IV Students at SDN Biro Palu. This research uses quantitative research by using experimental methods. The experimental design used in this study is quasi experimental design (quasi-experimental) in the form of nonequivalent control group design. The subjects in this study were all fourth grade students of SDN Palu Bureau. This sample is classified into 2 groups, namely the experimental class group and the control class group. Data analysis technique to answer the hypothesis in this study is to use the t-test. T-test analysis results indicate that the sign value. (2-tailed) of $0.001<0.05$. This means that $H \neg O$ which reads the ABC Games learning model has a positive effect on the value of critical thinking skills of Class IV SDN Palu Bureau students can be accepted. So it can be concluded that the ABC Games learning model has a positive effect on the value of students' critical thinking skills. This means that using the ABC learning model can improve students' critical thinking skills.
\end{abstract}

Key Words: ABC Games model, critical thinking skills, primary student

\section{PENDAHULUAN}

PAIKEM adalah singkatan dari Pembelajaran, Aktif, Inovatif, Kreatif, Efektif, Menantang dan Menyenangkan, yang tidak membuat peserta didik tertekan dan terbebani dengan tugas. Pembelajaran dengan PAIKEM didasarkan atas 2 asumsi. Pertama, bahwa belajar itu secara alami merupakan upaya kegiatan yang aktif, inovatif, dan kreatif.
Kedua, bahwa setiap peserta didik itu belajar dengan cara dan gayanya sendiri yang masingmasing berbeda dengan peserta didik lainnya (Aqib, 2017).

Pada pelaksanaan pembelajaran yang telah mengimplementasikan kurikulum 2013, guru sangat dimudahkan dalam membuat perangkat pembelajaran (RPP). Hal tersebut dikarenakan semua kegiatan yang akan 
dilakukan oleh guru dan siswa telah dijelaskan dalam Buku Guru dan Buku Siswa. Sehingga ketika pembuatan RPP, guru dapat menuliskan langsung pengalaman pembelajaran seperti yang tertulis dalam Buku Guru. Dalam Buku Guru, Kompetensi Inti (KI), Kompetensi Dasar (KD), Tujuan Pembelajaran, Pendekatan Pembelajaran, Media Pembelajaran, Sumber Belajar, Pengalaman Belajar, Penilaian, dan Rubrik Penilaian telah dikemas menjadi satu sesuai dengan tema.

Salah satu komponen yang tidak tersedia di dalam buku tersebut adalah model pembelajaran. Hal ini diasumsikan karena penggunaan model pembelajaran bergantung pada karakteristik siswa serta lingkungan belajar. Oleh karena itu, ketika membuat RPP, guru diminta menentukan model pembelajaran sendiri sesuai dengan karakteristik siswanya serta atmosfer kelasnya.

Guru dituntut lebih kreatif dalam mengemas perangkat pembelajaran sehingga proses pembelajaran menjadi interaktif, inspiratif, menyenangkan, memotivasi peserta didik untuk berpartisipasi aktif, serta memberikan ruang yang cukup bagi prakarsa, kreativitas, dan kemandirian sesuai dengan bakat, minat, dan perkembangan fisik serta psikologis peserta didik. Hal ini sesuai dengan Permendikbud Nomor 65 Tahun 2013.(Kemendikbud, n.d.)

Tetapi kondisi ideal di atas belum tercipta di SDN Biro Palu. Dalam proses pembelajaran, khususnya guru kelas IV di SDN Biro Palu tidak menggunakan model pembelajaran yang bervariasi. Model pembelajaran yang digunakan adalah tanya jawab, diskusi, ceramah dengan pendekatan sainstifik. Dengan proses belajar seperti ini, maka output yang diharapkan dari Permendikbud Nomor 65 Tahun 2013 belum tercapai.

Dari hasil wawancara dan observasi yang dilakukan dengan guru kelas IV, bahwa pelaksanaan proses pembelajaran selama ini telah mengikuti kurikulum 2013, yaitu menggunakan tema, dengan pendekatan sainstifik dan penilaian dilakukan pada aspek sikap, pengetahuan dan keterampilan. Untuk penggunaan model pembelajaran masih seperti biasanya yaitu tanya jawab, diskusi, kerja kelompok dan presentasi. Hal ini dilakukan karena para guru tidak punya banyak waktu untuk memikirkan metode mana yang cocok untuk pembelajaran saat itu. Mereka fokus pada prosedur penilaian. Prosedur penilaian yang digunakan adalah penilaian autentik. Jadi proses penilaiaan dilakukan sejak awal pembelajaran sampai selesai. Ketika presentasi hasil penilaian siswa, ada beberapa hal yang masih rendah khususnya pada kemampuan berpikir kritis.

Sebanyak 50,6\% siswa dari jumlah 30 siswa belum dapat mencari alternatif jawaban dari pertanyaan oleh guru. Mereka terpaku pada sumber buku siswa saja. Selain itu ketika ditanya alasan atas jawaban atau keputusan yang diberikan, mereka tidak dapat mengemukakannya. Jika hal ini dibiarkan berlalu begitu saja, maka para siswa tidak dapat bersikap bijaksana dalam menghadapi permasalahan. Sehingga tidak terbentuk pribadi yang mandiri pada diri mereka.

Salah satu alternatif pemecahan masalah di atas adalah dengan menerapkan model ABC Games dengan pendekatan sainstifik. Model ABC Games merupakan pengembangan dari model pembelajaran $\mathrm{ABC}$. Model ABC atau Anticipatio, Building Knowledge and Consolidation) merupakan merupakan akronim dari kata Anticipation, Building Knowledge, dan Consolidation. Model ini terdiri dari 3 tahap atau fase. yaitu anticipation atau antisipasi, building knowledge atau membangun pengetahuan, dan tahap ketiga adalah consolidation atau konsolidasi/menggabungkan. Pada tahap ini siswa diminta untuk menggabungkan hasil dari tahap pertama dan kedua.

\section{Model Pembelajaran ABC Games}

Model pembelajaran ABC Games merupakan pengembangan dari model pembelajaran $\mathrm{ABC}$. Model pembelajaran $\mathrm{ABC}$ merupakan akronim dari kata Anticipation, Building Knowledge, dan Consolidation. Model ini terdiri dari 3 tahap atau fase. Tahap pertama yaitu anticipation atau antisipasi. Pada tahap ini siswa diberikan permasalahan atau topik yang harus dipelajari, kemudian diminta untuk berpikir dan mengajukan pertanyaan atau permasalahan atau topik tersebut. Tahap/ atau fase kedua yaitu Building Knowledge atau membangun pengetahuan. Pada tahap atau fase ini meminta siswa untuk bertanya, mencari tahu, menjawab pertanyaan mereka sebelumnya, dan menemukan pertanyaanpertanyaan baru dari jawaban mereka. Tahap ketiga adalah Consolidation atau konsolidasi/menggabungkan. Pada tahap ini siswa diminta untuk menggabungkan hasil dari tahap pertama dan kedua. Siswa diminta untuk merenungkan apa yang telah mereka pelajari, kemudian menanyakan apa artinya bagi 
mereka, mencerminkan seperti apa perubahan yang mereka pikirkan, dan merenungkan bagaimana mereka dapat menggunakannya. (Saefuddin \& Berdiati, 2016)

Alan Crawford, Wendy Saul, Samuel R. Mathews, and James Makinster berpendapat model pembelajaran $\mathrm{ABC}$ yang terdiri dari Anticipation, Building Knowledge, dan Consolidation memiliki fungsi sebagai berikut. Fase Antisipasi berfungsi untuk (1) memanggil pengetahuan yang sudah dimiliki siswa, (2) secara informal menilai apa yang sudah mereka ketahui, termasuk kesalahpahaman, (3) menetapkan tujuan belajar, (4) memusatkan perhatian pada materi atau tema, (5) menyediakan materi untuk memahami ide-ide baru. Fase Building Knowledge: setelah pelajaran dimulai, pengajaran menuntun siswa untuk bertanya, mencari tahu, memahami materi, menjawab pertanyaan sebelumnya, dan menemukan pertanyaan baru. Fase ini berfungsi untuk: (1) membandingkan harapan dengan apa yang sedang dipelajari, (2) merevisi harapan atau menaikkan harapan baru, (3) mengidentifikasi poin utama, (4) memantau pemikiran pribadi, (5) membuat kesimpulan tentang materi, (6) membuat koneksi pribadi ke pelajaran, (7) mempertanyakan pelajaran. Menjelang akhir pelajaran, setelah siswa memahami ide-ide pelajaran, guru membimbing siswa melakukan refleksi tentang apa yang mereka pelajari. Fase Consolidation berfungsi untuk: (1) merangkum ide-ide utama, (2) menafsirkan gagasan, (3) berbagi pendapat, (3) membuat tanggapan pribadi, (4) menguji ide-ide, (5) menilai pembelajaran, (6) ajukan pertanyaan tambahan. (Crawford, Saul, Mathews, \& Makinster, 2005)

Model pembelajaran $\mathrm{ABC}$ games dalam penelitian ini yaitu penggunaan model pembelajaran $\mathrm{ABC}$ yang dikemas dalam bentuk permainan atau Games. Model ini bertujuan untuk memotivasi siswa untuk belajar dengan aktif dan menyenangkan. Dengan adanya games yang diberikan, siswa lebih antusias karena adanya persaingan untuk memenangkan games tersebut. Pada awal pembelajaran, siswa diajak untuk berbaris dengan urutan barisan A, B, dan C. Mereka berlomba menemukan jawaban-jawaban secara mandiri dan secara bersama-sama. Siswa dalam kelompok berkompetisi dalam meraih nilai atau skor.

Adapun langkah-langkah dalam model pembelajaran ABC Games yaitu sebagai berikut: a. Siswa diminta mempelajari materi dari berbagai media (buku, internet, perpustakaan, atau video pembelajaran). (Kegiatan mengamati)

b. Masing-masing siswa distimulasi untuk mengembangkan rasa ingin pahamnya dengan memberikan pertanyaanpertanyaan tingkat tinggi. (Kegiatan menanya).

c. uru membagi siswa ke dalam tiga kelompok. Masing-masing kelompok diminta memberi nama pada kelompoknya. Nama kelompok yaitu kelompok A, B, dan C

d. Guru meminta masing-masing kelompok untuk menciptakan yelyel untuk menyemangati pada saat games atau pada saat kelompok mendapatkan skor tinggi.

a. Siswa berdiskusi perkelompok untuk mempelajari dan membahas pertanyaanpertanyaan yang muncul dari materi yang diberikan. Masing-masing kelompok bertanggung jawab saling memintarkan.

b. Guru menyiapkan soal atau pertanyaan yang ditulis pada kartu atau kertas.

c. Siswa berbaris berbanjar per kelompok untuk mengikuti games. Anggota masingmasing kelompok mengikuti games dan secara estafet menjawab pertanyaan yang diajukan guru (Kegiatan menalar/mengolah informasi).

d. Salah satu siswa yang mewakili kelompok untuk maju ke dapan kelas dan memperlihatkan soal/pertanyaan yang sudah ditulis di kertas atau kartu pada siswa di depan kelas. Soal belum boleh diberitahukan kepada peserta lainnya. (Kegiatan mengolah informasi).

e. Siswa yang mengikuti lomba harus menjawab sendiri soal dengan menuliskan jawaban di media yang sudah disediakan. Siswa dapat dibantu oleh anggota lainnya. Setelah hitungan 1-10 (waktu boleh disesuaikan) siswa boleh meminta bantuan seluruh anggota kelompoknya untuk menjawab soal sampai batas waktu yang sudah ditentukan. (Kegiatan mengolah informasi).

f. Setelah selesai soal pertama, guru meminta siswa lain dalam kelompok maju ke depan untuk melanjutkan games untuk menjawab soal kedua dan seterusnya dengan cara yang sama.

e. Siswa bersama guru menganalisis hasil jawaban siswa dan memberitahu jawaban yang benar, setiap siswa menjawab soal dalam games. Setiap kelompok yang 
mendapatkan skor tertinggi merayakannya dengan meneriakkan yel-yel kelompok (Kegiatan komunikasi).

f. Guru menilai proses lomba dan hasil jawaban setiap soal yang dikerjakan. Pada akhir pembelajaran menjumlahkan skor. Bila memungkinkan guru memberikan reward kepada pemenang lomba. (Saefuddin \& Berdiati, 2016)

\section{Kemampuan Berpikir Kritis}

Berpikir kritis menurut Hassoubah (Agusman, 2016) yaitu berpikir yang berhubungan dengan apa yang seharusnya dipercaya atau dilakukan setiap situasi atau peristiwa. Ada 2 hal tanda utama dalam berpikir kritis. (1) bahwa berpikir kritis adalah berpikir layak yang memandu ke arah berpikir deduksi dan pengambilan keputusan yang benar dan didukung oleh bukti-bukti yang benar. (2) berpikir kritis adalah berpikir reflektif yang menunjukkan kesadaran yang utuh dari langkah-langkah berpikir yang menjurus kepada deduksi-deduksi dan pengambilan keputusan-keputusan.

Menurut Alvino (Agusman, 2016), berpikir kritis merupakan bagian dari keterampilan atau kemampuan berpikir tingkat tinggi karena meliputi proses analisis, sintesis, dan evaluasi. Keterampilan berpikir merupakan proses mental yang terjadi ketika berpikir. Ruggiero dalam (Nasir \& Buhaerah, 2017) mengemukakan bahwa berpikir kritis merupakan aktivitas mental yang menguji, mempertanyakan, menghubungkan, dan mengevaluasi semua aspek yang ada dalam suatu situasi atau masalah. Sedangkan Cambell berpendapat bahwa berpikir kritis merupakan proses intelektual yang aktif dan terampil mengkonseptualisasi, mengaplikasikan, menganalisis, mensintesis, atau mengavaluasi informasi dari hasil observasi.

Dari beberapa pendapat di atas dapat disimpulkan bahwa berpikir kritis adalah aktivitas berpikir yang aktif dan terampil menguji, menghubungkan, mengaplikasikan, mengsintesis dan mengevaluasi informasi dalam suatu situasi atau masalah.

Kirschenbaum dalam (Zuchdi, Zuhdan, \& Muhsinatun, 2013) mengatakan bahwa ciri-ciri orang yang berpikir kritis adalah (1) mencari kejelasan pernyataan atau pernyataan, (2) mencari alasan, (3) mencoba memperoleh informasi yang benar, (4) menggunakan sumber daya yang dapat dipercaya, (5) mempertimbangkan keseluruhan situasi, (6) mencari alternatif, (7) bersikap terbuka, (8) mengubah pandangan apabila ada bukti yang dapat dipercaya, (9) mencari ketepatan suatu permasalahan, (10) sensitif terhadap perasaan, tingkat pengetahuan, dan tingkat kecanggihan orang lain.

Sedangkan beberapa karakteristik siswa yang mampu berpikir kritis dijelaskan Lau sebagai berikut: (1) mampu memahami hubungan logis antara ide-ide, (2) mampu merumuskan ide secara ringkas dan tepat, (3) mampu mengidentifikasi, membangun, dan mengevaluasi argumen, (4) mampu mengevaluasi keputusan, (5) mampu mengevaluasi bukti dan mampu merumuskan hipotesis, (6) mampu mendeteksi inkonsistensi dan kesalahan umum dalam penalaran, (7) mampu menganalisis masalah secara sistematis; (8) mampu mengidentifikasi relevan dan pentingnya ide, (9) mampu menilai keyakinan dan nilai-nilai yang dipegang seseorang, dan (10) mampu mengevaluasi kemampuan berpikir seseorang (Aslan, 2018). Indikator kemampuan berpikir kritis (IKBK) dalam (Rofiah, Aminah, \& Ekawati, 2013) yaitu: (1) mengajukan pertanyaan, (2) merencanakan strategi, dan (3) mengevaluasi keputusan.

Thyer membagi keterampilan berpikir kritis menjadi menjadi 6 tahap yaitu:

1. Observasi

Menentukan informasi apa yang dapat diperoleh, memperoleh informasi dari berbagai sumber, memastikan informasi apa yang ada pada saat ini, mengeksplorasi pandangan yang berbeda, mengidentifikasi kesamaan dan perbedaan.

2. Analisis

Mengurai informasi ke dalam tema-tema atau argumen-argumen utama

3. Evaluasi

Mendiskriminasi nilai dari informasi, memprioritaskan informasi penting, membedakan opini dan fakta.

4. Kontekstualisasi

Kontekstualisasi informasi dalam hubungannya dengan sejarah, etika, politik, budaya, lingkungan.

5. Bertanya

Mempertimbangkan alternatif yang mungkin dan mengembangkan hipotesis baru.

6. Refleksi

Menanyakan dan menguji kesimpulan, refleksi dampak yang mungkin (Sani, 2019). 
Crawford, Saul, Mathews \& Makinster telah menyebutkan pentingnya berpikir kritis yaitu:

a. Berpikir kritis membantu menafsirkan informasi seperti kemampuan untuk secara kritis menganalisis, mengenali informasi yang salah dan mengaktifkan siswa.

b. Membantu membuat keputusan yang lebih baik tentang tindakan yang akan dilakukan.

c. Mendorong untuk memikirkan prasangka sendiri.

d. Menantang cara berpikir baik dalam bidang sosial, politik, dan budaya.

e. Mendorong untuk melangkah lebih rasionalitas, serta menggunakan kreativitas untuk keluar dari pengetahuan dan pemahaman tradisional.

f. Membantu mengkritik, menolak atau beradaptasi pada alat dan metode yang digunakan dalam kelas sehingga lebih bertanggung jawab. (Thapaliya, 2013)

\section{METODE PENELITIAN}

Penelitian ini menggunakan jenis penelitian kuantitatif dengan menggunakan metode eksperimen. Desain eksperimen yang digunakan dalam penelitian ini yaitu quasi eksperimental design (eksperimen semu) bentuk nonequivalent control group design. Metode penelitian eksperimen adalah metode penelitian yang digunakan untuk mencari pengaruh perlakuan tertentu terhadap yang lain dalam kondisi yang terkendalikan (Sugiyono, 2015). Desain ini digunakan karena dalam pelaksanaan penelitian, peneliti tidak dapat mengontrol seluruh variabel. Selengkapnya dapat dilihat pada tabel 3.1 sebagai berikut.

Tabel 3.1

Desain penelitian

\begin{tabular}{|l|l|l|}
\hline O1 & $\mathrm{X}$ & $\mathrm{O} 2$ \\
\hline $\mathrm{O} 3$ & & $\mathrm{O} 4$ \\
\hline
\end{tabular}

Sumber: (Sugiyono, 2015)

$$
\begin{aligned}
\text { Keterangan } & \\
\mathrm{O} 1 \text { dan } \mathrm{O} 3 & =\text { pretest } \\
\mathrm{O} 2 \text { dan } \mathrm{O} 4 & =\text { posttest } \\
\mathrm{X} & =\text { Model } \mathrm{ABC} \text { Games }
\end{aligned}
$$

Subjek dalam penelitian ini adalah seluruh siswa kelas IV SDN Biro Palu. Sampel ini diklasifikasi ke dalam 2 kelompok yaitu kelompok kelas eksperimen dan kelompok kelas kontrol. Kelompok kelas eksperimen adalah siswa kelas IVA, dan kelompok kelas kontrol adalah siswa kelas IVB. Instrumen yang digunakan adalah kuesioner keterampilan berpikir siswa yang telah valid dan reliable. Ujicoba instrumen dilakukan di kelas IV SD Inpres Birobuli. Jumlah item pernyataan dalam kuesioner yang telah valid dan reliable sebanyak 16 Pernyataan.

Analisis data dalam bentuk deskripsi dan statistic inferensial. Analisis deskripsi data bertujuan untuk meberikan gambaran tentang nilai keterampilan berpikir kritis siswa. Mengacu pada pendapat Kunandar (Kunandar, 2014), penilaian sikap dapat menggunakan kategori berikut.

Tabel 1

Kriteria Keterampilan Berpikir Kritis

\begin{tabular}{ll}
\multicolumn{2}{c}{ Kriteria Keterampilan Berpikir Kritis } \\
\hline Nilai & Kategori \\
$91-100$ & Sangat Kritis \\
$71-90$ & Kritis \\
$61-70$ & Cukup Kritis \\
Kurang dari 61 & Tidak Kritis \\
\hline
\end{tabular}

Teknik analisis data untuk menjawab hipotesis dalam penelitian ini adalah menggunakan Uji-t. Rumus uji-t tersebut yaitu:

$$
t_{\text {hitung }}=\frac{x_{1}-x_{2}}{s_{\text {gabungan }}-\sqrt{\frac{n_{1}+n_{2}}{n_{1} \cdot n_{2}}}}
$$

Hipotesis dalam penelitian ini yaitu:

$H_{O}=$ Model pembelajaran $A B C$ Games berpengaruh positif terhadap nilai keterampilan berpikir kritis siswa Kelas IV SDN Biro Palu.

$H a$ = Model pembelajaran $A B C$ Games tidak berpengaruh positif terhadap nilai keterampilan berpikir kritis siswa Kelas IV SDN Biro Palu. 


\section{HASIL \& PEMBAHASAN}

Chafersman,

mendefinisikan

keterampilan berpikir kritis sebagai keterampilan logika analitis, masuk akal, berpikir tingkat tinggi, reflektif, ilmiah dan bernalar. Demikian pula, Chance mendefinisikan berpikir kritis sebagai kemampuan menganalisis fakta, menghasilkan dan mengatur ide, pertahankan opini, membuat dan menggambarkan perbandingan, (Thapaliya, 2013).

Indikator keterampilan berpikir kritis menurut Tyler yang digunakan dalam penelitian ini yaitu observasi, analisis, evaluasi, kontekstual, bertanya, dan refleksi.
Berdasarkan hasil penelitian didapatkan bahwa nilai pretes keterampilan berpikir kritis sebagai berikut. Nilai keterampilan berpikir kritis pada saat pretes atau sebelum perlakuan diberikan pada kelas kontrol dan kelas eksperimen ratarata pada kategori cukup kritis. Pada kelas control terdapat 4 indikator yang berkategori cukup kritis, 2 indikator berkategori kritis dan 1 indikator dengan kategori belum kritis. Pada kelas eksperimen, 3 indikator yang berkategori cukup kritis dan 3 indikator berkategori kritis. Nilai keterampilan kemampuan berpikir kritis pada kelas kontrol dan kelas eksperimen dapat dilihat pada tabel 2 berikut.

Tabel 2 Nilai Pretes Keterampilan Berpikir Kritis

\begin{tabular}{llclcl}
\hline \multirow{2}{*}{ No } & \multirow{2}{*}{ Indikator } & \multicolumn{2}{c}{ Kelas Kontrol } & \multicolumn{2}{c}{ Kelas Eksperimen } \\
\cline { 3 - 6 } & & Nilai & Kategori & Nilai & Kategori \\
\hline 1 & Observasi & 72,5 & kritis & 65,8 & Cukup kritis \\
2 & Analisis & 63,8 & Cukup kritis & 76,3 & Kritis \\
3 & Evaluasi & 65,6 & Cukup kritis & 62,5 & Cukup kritis \\
4 & Kontekstual & 69,2 & Cukup kritis & 71,3 & Kritis \\
5 & Bertanya & 72,9 & kritis & 76,3 & Kritis \\
6 & Refleksi & 59,4 & Tidak kritis & 60,6 & Cukup kritis \\
\hline & Rata-rata & $\mathbf{6 7 , 2 3}$ & & $\mathbf{6 8 , 8}$ & \\
\hline
\end{tabular}

Setelah pelaksanaan pretes, kemudian dilakukan perlakuan pada kelas eksperimen. Perlakuan yang diberikan berupa pembelajaran dengan menerapkan model ABC. Pembelajaran ini dilaksanakan di semester I pada tema 1 Organ Gerak Hewan dan Manusia dengan sub tema 2 Manusia dan Lingkungan. Sedangkan pada kelas kontrol tidak diberikan perlakuan. Pembelajaran yang dilakukan seperti biasanya. Tahap selanjutnya yaitu melaksanakan postes di dua kelas. Kegiatan ini bertujuan untuk mengetahui keterampilan berpikir kritis siswa setelah melaksanakan pembelajaran dengan model ABC. Adapun hasil dari kegiatan postes yaitu pada kelas control indicator observasi dan refleksi pada kategori kritis. Sedangkan indicator analisis, evaluasi, kontekstual, dan refleksi pada kategori cukup kritis. Pada kelas eksperimen hasil yang diperoleh yaitu indicator observasi, analisis, evaluasi, kontekstual, dan bertanya pada kategori kritis dan indicator refleksi dengan kategori cukup kritis. Indicator keterampilan berpikir kritis pada kelas eksperimen dapat dikatakan rata-rata pada kategori kritis. Nilai keterampilan berpikir kritis siswa pada kelas control dan eksperimen selengkapnya dapat dilihat pada tabel 3 berikut.

Tabel 3 Nilai Postes Keterampilan Berpikir Kritis

\begin{tabular}{llclcc}
\hline \multirow{2}{*}{ No } & \multirow{2}{*}{ Indikator } & \multicolumn{2}{c}{ Kelas Kontrol } & \multicolumn{2}{c}{ Kelas Eksperimen } \\
\cline { 3 - 6 } & & Nilai & Kategori & Nilai & Kategori \\
\hline 1 & Observasi & 72,5 & kritis & 74,2 & Kritis \\
2 & Analisis & 68,8 & Cukup kritis & 77,5 & Kritis \\
3 & Evaluasi & 66,6 & Cukup kritis & 73,8 & Kritis \\
4 & Kontekstual & 69,2 & Cukup kritis & 76,3 & Kritis \\
5 & Bertanya & 74,6 & kritis & 78,8 & Kritis \\
6 & Refleksi & 64,4 & Cukup kritis & 65,6 & Cukup kritis \\
\hline & Rata-rata & $\mathbf{6 9 , 4}$ & & $\mathbf{7 4 , 4}$ & \\
\hline
\end{tabular}

Berdasarkan nilai pretes dan postes terdapat perbedaan hasil pada kelas control dan kelas eksperimen. Nilai rata-rata pada kelas control yaitu 69,4 sedangkan pada kelas 
eksperimen sebesar 74,4. Perbedaan perolehan hasil ini disebabkan karena perlakuan yang berbeda pada kelas control dan kelas ekperimen. Pada kelas eksperimen diberikan perlakuan pembelajaran dengan menggunakan model ABC. Sehingga dapat dikatakan bahwa model pembelajaran $\mathrm{ABC}$ dapat meningkatkan keterampilan berpikir kritis siswa. Pengaruh perlakuan pembelajaran dengan model pembelajaran $\mathrm{ABC}$ dapat diketahui dengan analisis data menggunakan uji-t. Hasil analisis data dengan uji-t dapat dilihat pada tabel 4 berikut.

Tabel 4 Hasil analisis dengan uji-t

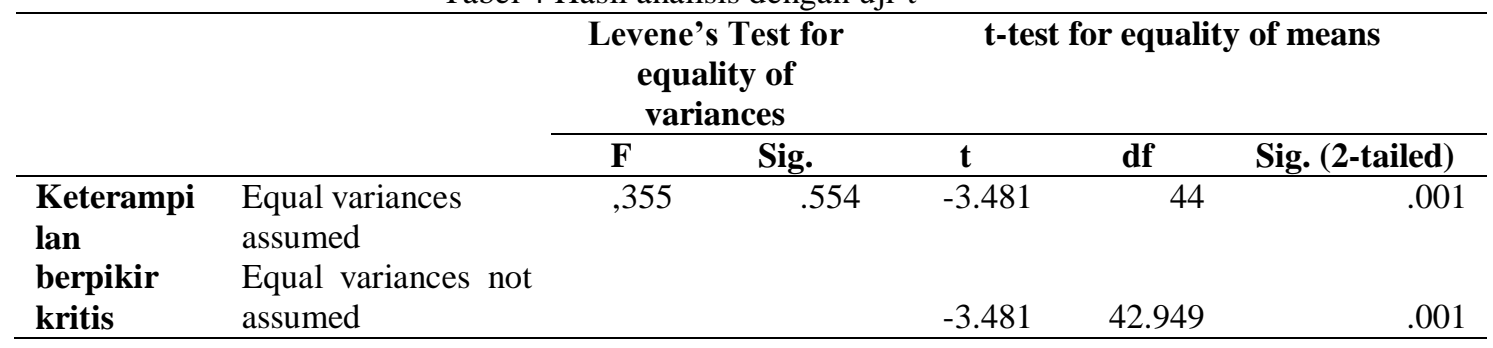

Hasil analisis uji-t pada tabel 4 menunjukan bahwa nilai sign. (2-tailed) sebesar $0,001<0,05$. Hal ini berarti bahwa $\mathrm{H}_{\mathrm{o}}$ yang berbunyi Model pembelajaran $A B C$ Games berpengaruh positif terhadap nilai keterampilan berpikir kritis siswa Kelas IV SDN Biro Palu dapat diterima. Sehingga dapat disimpulkan bahwa Model pembelajaran $A B C$ Games berpengaruh positif terhadap nilai keterampilan berpikir kritis siswa. Artinya penggunakan model pembelajaran $\mathrm{ABC}$ dapat meningkatkan keterampilan berpikir kritis siswa.

Model pembelajaran ABC merupakan akronim dari Anticipation, Building Knowledge, dan Consolidation. Menurut Alan Crawford, Wendy Saul, Samuel R. Mathews, and James Makinster pada Fase Antisipasi siswa diminta untuk memanggil kembali pengetahuan yang sudah dimiliki siswa. Pada saat ini secara informal guru dapat menilai apa yang sudah mereka ketahui, termasuk kesalahpahaman. Kemudian siswa diminta untuk menetapkan tujuan belajar dengan fokus pada materi. Pada Fase Building Knowledge: siswa dituntun untuk bertanya, mencari tahu, memahami materi, menjawab pertanyaan sebelumnya, dan menemukan pertanyaan baru. Tahap ini dapat membangun keterampilan siswa untuk melakukan observasi, mengalisis, mengevaluasi dan bertanya. Pada bagian akhir yaitu Fase Consolidation siswa diminta untuk merangkum ide-ide utama, menafsirkan gagasan, berbagi pendapat, membuat tanggapan pribadi, menguji ide-ide, menilai pembelajaran, dan ajukan pertanyaan tambahan. Tahap atau fase ini mengembangkan keterampilan siswa untuk mengevaluasi, kontekstualisasi, bertanya dan melakukan refleksi. Selain itu menurut Fadila dan Slameto Peserta didik dapat berfikir kritis melalui penyelesaian masalah. Seperti menggunakan puzzle yang menuntut peserta didik untuk berfikir kritis dan menyelesaikan setiap pemecahan masalah yang berkaitan dengan kehidupan sehari-hari (Fadila \& Slameto, 2018)

\section{KESIMPULAN \& SARAN}

Berdasarkan hasil penelitian yang telah dilakukan dapat ditarik kesimpulan yaitu Model pembelajaran $A B C$ Games berpengaruh positif terhadap nilai keterampilan berpikir kritis siswa. Artinya penggunakan model pembelajaran $\mathrm{ABC}$ dapat meningkatkan keterampilan berpikir kritis siswa. Penggunaan model ABC Games melatih siswa untuk dapat membangun pengetahuan mereka sendiri dari pengetahuan yang telah ketahui dikaitkan dengan materi yang sedang dipelajari kemudian dapat membuat penafsiran atau menguji ide-ide yang telah ada. Dengan cara ini, siswa dilatih mandiri sehingga mampu berpikir kritis terhadap ide-ide atau permasalahan yang ada. Dari hasil penelitian ini, disarankan agar dalam pembelajaran tidak hanya menekankan pada kemampuan kognitif, tetapi juga meningkatkan skill atau keterampilan siswa agar mereka dapat memecahkan permasalahan sehari-hari yang lebih kompleks dengan cara yang benar dan tepat. Peningkatkan keterampilan bagi siswa dapat dilakukan dengan penerapan modelmodel pembelajaran yang bersifat konstruktif terhadap ide atau pemikiran siswa. 


\section{DAFTAR PUSTAKA}

Agusman. (2016). Desain Model Pembelajaran Matematika yang Mengembangkan Kemampuan Berpikir Kritis. Jurnal Pendidikan Matematika, 2(2).

Aqib, Z. (2017). Model-model dan Strategi Pembelajaran Kontekstual (Inovatif). Bandung: Yrama Widya.

Aslan, S. (2018). The Relationship Between Critical Thinking Skills and Democratic Attitudes of 4th Class Primary School Students. International Journal of Progressive Education, 14(6), 61-69. https://doi.org/10.29329/ijpe.2018.179. 5

Crawford, A., Saul, W., Mathews, S. R., \& Makinster, J. (2005). Teaching And Learning Strategies For The Thinking Classroom. New York: The International Debate Education Association.

Fadila, A. N., \& Slameto. (2018). Peningkatan Hasil Belajar Pemecahan Masalah Matematika Melalui Problem Based Learning berbasis Critical Thinking. Jurnal Publikasi Pendidikan, 8(3), 201-205.

Kemendikbud. Peraturan Perintah NO 65 Tahun 2013.

Kunandar. (2014). Penilaian Autentik (Penilaian Hasil Belajar Peserta Didik Berdasarkan Kurikulum 2013). Jakarta: RajaGrafindo Persada.

Nasir, M. A. D., \& Buhaerah. (2017). Model pembelajaran berpikir kritis yang terintegrasi nilai-nilai Islam. Prosiding Seminar Nasional Integrasi Matematika Dan Nilai Islam, 1(1).

Rofiah, E., Aminah, S., \& Ekawati, E. Y. (2013). Penyusunan Instrumen Tes Kemampuan Berpikir Tingkat Tinggi Fisika Pada Siswa SMP. 1(2), 17-22.

Saefuddin, A., \& Berdiati, I. (2016). Pembelajaran Efektif. Bandung: Remaja Rosdakarya.

Sani, R. A. (2019). Pembelajaran Berbasis HOTS (Higher Order Thinking Skills). Tangerang: Tira Smart.

Sugiyono. (2015). Metode Penelitian Kuantitatif, Kualitatif, dan $R \& D$. Bandung: Alfabeta.

Thapaliya, M. P. (2013). Teaching Short Story through Critical Thinking (CT) Strategies. Journal of NELTA, 17(12), https://doi.org/10.3126/nelta.v17i12.8101

Zuchdi, D., Zuhdan, K. P., \& Muhsinatun, S. (2013). Model Pendidikan Karakter. Yogyakarta: Multi Persindo. 